\title{
WORK SAFETY WITH USAGE OF THE MACHINES - METHODOLOGY OF AN EVALUATION OF FULFILLING THE REQUIREMENTS OF LEGAL REGULATIONS
}

\author{
Tomasz MAŁYSA \\ Politechnika Śląska, Wydział Inżynierii Materiałowej; tomasz.malysa@ polsl.pl, ORCID: 0000-0002-9352-0528
}

Purpose: The methodology for assessing compliance with legal requirements in machine plant purchased old and new (often imported from third countries) and used in Polish industry was presented. Application of the presented methodology may be one of the actions allowing verification compliance with legal requirements.

Design/methodology/approach: The advanced methodology for assessing machinery compliance with legal requirements.

Findings: On the basis of research and analyzes, non-compliance in the scope of minimum requirements was found. A proposal of solutions improving the safety of the analyzed machine plant was also presented.

Research limitations/implications: Safety related to machine operation plays a key role for the EU economy. Therefore, the utilized machinery meeting legal requirements is an important element. The author, in carrying out machine compliance assessments, will present in subsequent studies research on safety areas for which the occurrence of non-compliance is most often identified.

Practical implications: Application of the developed methodology may facilitate the implementation of works related to the assessment of machine safety.

Social implications: The implementation of solutions focused on ensuring work safety is a manifestation of the involvement of the top management in shaping the OSH culture.

Originality/value: The article presents a proposal for a methodology for assessing whether the machine plant used in industry meet with compliance to legal requirements. The presented methodology can be used by producers and employers.

Keywords: safety usage of machines, methodology for assessing compliance with legal requirements, minimum and essential requirements.

Category of the paper: technical paper, viewpoint. 


\section{Introduction}

Providing employees with safe and healthy working conditions is one of the basic duties of every employer. Therefore, they should take all possible actions aimed at providing broadly understood security in the place where the work is performed, including ensuring safety in machine operation. In accordance with applicable legal regulations, the machinery used in industrial enterprises should meet the requirements set out in the New Approach Directives, implemented in national law and defined by the EU (national) legislation. The legal regulations specify safety requirements that should be meet by machines available for purchase within the European market, as well as those already in use.

The European Union is involved in activities aimed at improving work safety in the usage of machinery. This is due to the fact that the engineering industry is one of the main pillars of the Community economy. The activities undertaken in this area concern the design and construction of machines so that they meet with European Union standards of safe operation. The concept adopted in this way is focused on activities contributing to reducing the number of accidents at work that occur when using industrial plant.

The aim of the article is to develop the methodology of the approach to the assessment of compliance with the requirements of legal provisions provided for machines operated in industrial enterprises. The study presents the possibility of adapting to the legal requirements, a machine used for rolling rubber and plastics. For the analyzed machine, non-conformities in the scope of legal requirements were identified. Implementation of corrective actions for the identified non-conformities, based on technical solutions provided for in harmonized standards with the Machinery Directive, was proposed. The approach presented in the article for the assessment of compliance can be used to measure a machine's potential to meet minimum or essential requirements. It can also be used in implementing preventive solutions to bring it up to code (the effectiveness of implementation of risk mitigation solutions - risk assessment before and after putting into practice protective activities).

\section{Safety requirements for machines}

Ensuring that the machinery which is put on the EU market / used in companies meets the safety requirements rests with the entities selling it (producer, importer) or using it (employer). The time limit determining the type of requirements to which the machine is subject to was the date of the country's accession to the EU structures, (May 1st, 2004). Accordingly, there are two types of safety requirements for machines, i.e.: essential requirements (concerning new machines) and minimum requirements (concerning old machines) used before the country's 
accession to the EU structures (Małysa et al., 2015; Łabanowski, 2012; Małysa, Pawlak, 2017; Małysa et al., 2013).

New machines constitute a group of products placed on the market or put into use in the single EU market since the accession of the country to the EU structures. The entities putting it into service (manufacturer, distributor, importer) became responsible for ensuring that the item meets the applicable regulations (Dyrektywa, 2006; Rozporządzenie Ministra Gospodarki, 2008). However, according to the Labor Code (Kodeks pracy, 1974), the employer is responsible for ensuring safety when his employees use new machine plant. Hence, the employer is obliged to equip work stands with machines and other technical devices that meet or exceed the requirements for conformity to specified health and safety regulations. The conformity assessment applies to the Act on conformity assessment systems and market surveillance (Ustawa, 2016), in which the system of fines for failure to comply with legal provisions and the introduction of machines (other products) that do not meet the essential requirements have been defined. Therefore, the owner is obliged to not only ensure safety when his or her employees use his/her industrial plant, but also to maintain these machines according to the above-mentioned legal requirements.

The minimum requirements are addressed to the activity of the entities owning the machines, i.e. the employers. According to the Tool Directive (Dyrektywa, 2009) and national law laid down by regulation (Rozporządzenie Ministra Gospodarki, 2002) regarding minimum safety requirements for the use of machines by workers, it is the employer's obligation to take actions to meet requirements that are also defined by the legislator in the Labour Code. According to art. 215 of the Labor Code, the employer is obliged to ensure that his employees work within safe and hygienic conditions, and, in particular, are protected from potential injuries, hazardous chemicals, electric shock, excessive noise, mechanical vibrations and radiation, as well as other harmful and dangerous work environment factors. The operated machines should also take into account the principles of ergonomics. When such machinery does not meet the requirements described in Article 215 of the Labor Code, the statutory task of the employer is to undertake actions aimed at equipping the machines with appropriate safeguards, depending on the working conditions specific to the company.

In Poland, the various technical aspects related to work safety in the use of machinery described in the regulations (Rozporządzenie Ministra Gospodarki, 2002; 2008) also include regulations on general health and safety set out in Rozporządzenie Ministra Pracy i Polityki Socjalnej (1997). The third chapter of the regulation deals with the operation and use of machinery, tools and technical equipment and is consistent with the regulation regarding minimum (Rozporządzenie Ministra Gospodarki, 2002) and essential (Rozporządzenie Ministra Gospodarki, 2008) requirements. Of note, such legislation state that all industrial plant must meet safety requirements for the entire period of their operation. 


\section{The methodology for assessment of compliance witch legal requirements}

The assessment of compliance with legal requirements of the machinery operated in manufacturing enterprises requires a methodical approach to the stated problem, which is meeting the legal requirements for the machinery. The legislator has divided the security requirements into minimal and essential. However, often in the industrial practice, both used and new machines do not meet the requirements described in the legal provisions. The solution to this problem may be a methodical approach to the assessment of the compliance of the machines with the minimum or essential safety requirements (which requires determining the type of requirements that apply to the analyzed machine) before putting them into service. Fig. 1 presents the methodology of the approach to the assessment of the compliance of industrial plant with the requirements of the legislator, which highlights:

- identification of facilities, determining the date of their production - within this stage, the machines used in the company should be identified, the date of their production should be able to be read from the nameplate, and the existing technical documentation should be assigned to them. Determining the date of production will allow to determine the type of requirements (essential/minimum) to be met, in the scope of which they should be maintained, in order to provide the user with the level of occupational health and safety and ergonomics required by law. Basing on the established type of requirements, it is necessary to draw up legal acts concerning safety requirements that should be considered in the aspect of the analyzed machine, i.e. directives and transferring them to the national law regulations of competent ministers or regulations dedicated to a given group of machines - e.g. woodworking machines;

- a list of security-related areas and assessment of compliance with legal requirements all areas relating to technical aspects related to the machine being used should be listed, e.g. control elements, control systems, covers or protective devices, machine stability etc. This stage assesses whether legal requirements are met for a given safety area or not. Omitting this area may result in the lack of implementation of solutions intended to reduce the risk of accident. At this stage, it is necessary to pay attention to the validity of the applicable legal acts;

- identification of hazards and risk assessment - at this stage, the hazards occurring in the analyzed areas of safety, e.g. related to the control elements, machine stability etc. should be identified. Hazard identification is an important step in the methodology and subsequently in risk reduction. The risk assessment may be performed based on the PN-EN ISO 12100:2012 standard (Standard PN-EN ISO 12100:2012). A detailed risk assessment should be carried out for both old machines (minimum requirements) and new ones (essential requirements); 
- determination of existing discrepancies according to existing legislation, selected standards - analysis of the areas for which non-compliance was registered - failed to comply with legal requirements. For these areas, actions to meet the legislator's requirements are defined. At this stage, the costs of work adjustment can be estimated;

- elimination, reduction of occurring discrepancies - to eliminate the identified discrepancies, the solutions provided in European standards can be used. The harmonized standards are one of the ways to meet the requirements of the legislator (the presumption of conformity principle). At this stage, the solutions are enacted to eliminate or limit the non-compliances. The elimination of existing discrepancies is possible thanks to the implementation of solutions, most often a combination of technical and organizational measures;

- risk assessment - assessment of the effectiveness of implementing risk mitigation solutions - the stage at which the effectiveness of implemented solutions limiting the accident risk is assessed. The risk assessment process should be carried out again, and the answer should be given whether the solutions applied have not contributed to the occurrence of new threats. In case of such occurrence, the process of its reduction should be started again;

- the introduction of implemented changes to the technical documentation the implemented changes require their introduction into the technical documentation of the analyzed machine. At this stage, the relevant documents resulting from the application of the Machinery Directive, such as the declaration of conformity and the $\mathrm{CE}$ marking (in the case of machines subject to the essential requirements) should be worked out.

A methodical approach to the assessment of compliance with the requirements of the legislator may be an effective tool, the use of which may support the implementation of work aimed at improving safety and maintenance of industrial plant in the scope of legal requirements (minimum or essential). 
Identification of facilities, determining the date of their production

(selection of safety requirements for machines)

Machines usage in enterprises before Poland joined the EU structures
Machines placed on the market / put into service after Poland's accession to EU

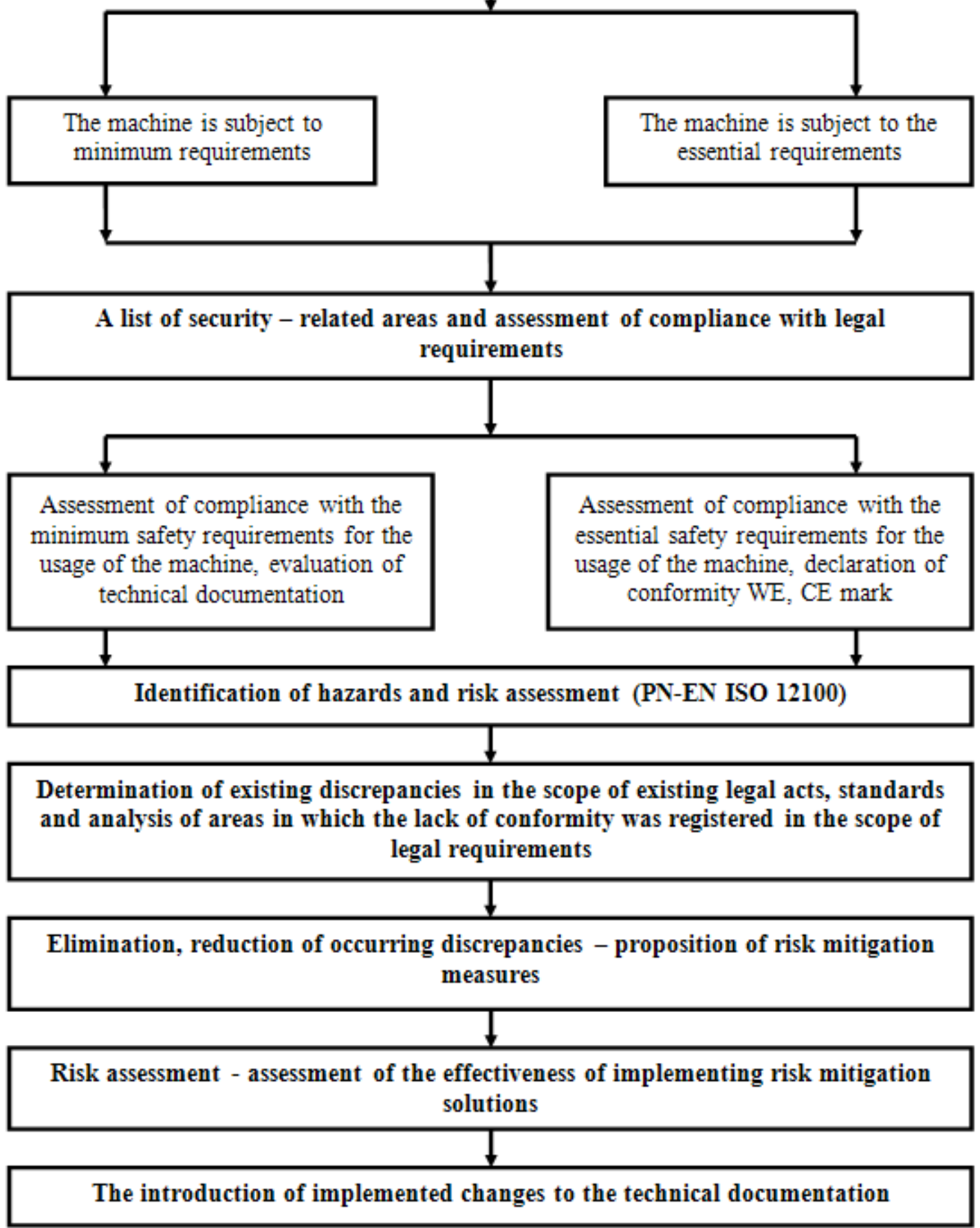

Figure 1. Methodology of approach to the assessment of meeting legal requirements (minimum and essential). Source: own elaboration. 


\section{The adaptation of the developer methodology in industrial conditions}

The study presents the adaptation of the developed methodology of approach to the assessment of industrial machine compliance with legal requirements. The analysis meets the legislator's requirements for a machine for rolling rubber and plastics. The machine was produced in the seventies of the last century. It is used for plastification of natural and synthetic rubber, as well as mixing and heating of un-vulcanized rubber mixtures.

Following the assumptions of the adopted methodology (fig. 1), the object was identified and the date of production was determined. On this basis, the requirements for the machine are identified. The machine was produced in the seventies and therefore should meet the minimum requirements, and in the scope of these requirements, be maintained throughout its lifetime. In connection with the above, legal acts that specify legal requirements for old machines used in enterprises have been compiled. These legal acts include:

- Directive 2009/104/WE of the European Parliament and of the Council of 16 September 2009 concering the minimum safety and health requirements for the use of work equipment by workers at work (DN).

- Regulation of the Minister of Economy of 30 October 2002 on minimum safety and hygiene requirements for the use of machines by workers at work (RMG).

- Regulation of the Minister of Labor and Social Policy of 26 September 1997 on general health and safety at work regulations (RMPiPS).

On the basis of the compiled legal acts, the areas for which attention should be paid in the process of assessing the fulfilment of legal requirements have been identified. The study presents the sample areas related to:

- $\quad$ equipment control devices - § 9.1-9.2 (RMG), p. 2.1 (DN); § 52.3-52.4 (RMPiPS);

- completely and safely stopping - § 13.1 (RMG), p. 2.3 (DN), § 52.1 (RMPiPS);

- $\quad$ emergency stop - $\S 14.1$ (RMG), p. 2.4 (DN), § 52.2 (RMPiPS);

- $\quad$ thrown objects, falling objects $-\S 14.2$ (RMG), p. $2.5(\mathrm{DN})$;

- $\quad$ guards and protection devices - $§ 15.3$ (RMG), p. 2.8 (DN), § 55.1 (RMPiPS);

- $\quad$ stability of the machinery - $\S 15.1$ (RMG), p. $2.6(\mathrm{DN})$;

- warnings and markings necessary to ensure the safety of employees $-\S 18$.1.2. (RMG), p. $2.15(\mathrm{DN})$.

For the specified areas related to safety, the threats have been identified for which the source, effect and estimated risk of possible negative health effects was determined. The risk assessment was based on the method of preliminary hazard analysis (PHA method). It is a qualitative, indicative method in which the risk is estimated as the product of two parameters, i.e. the probability of "P" and the severity of the consequences of "S" (Lis, Nowacki, 2005; Małysa, Pawlak, 2017; Szlązak, Szlązak, 2012). The characteristics of individual parameters are summarized in Table 1. Owing to the fact that this is a preliminary 
risk analysis method, used at the beginning of activities related to risk reduction for the analyzed machine, the employer should, after completing all work, carry out a risk assessment once again.

Table 1.

The scale of assessments of risk parameters

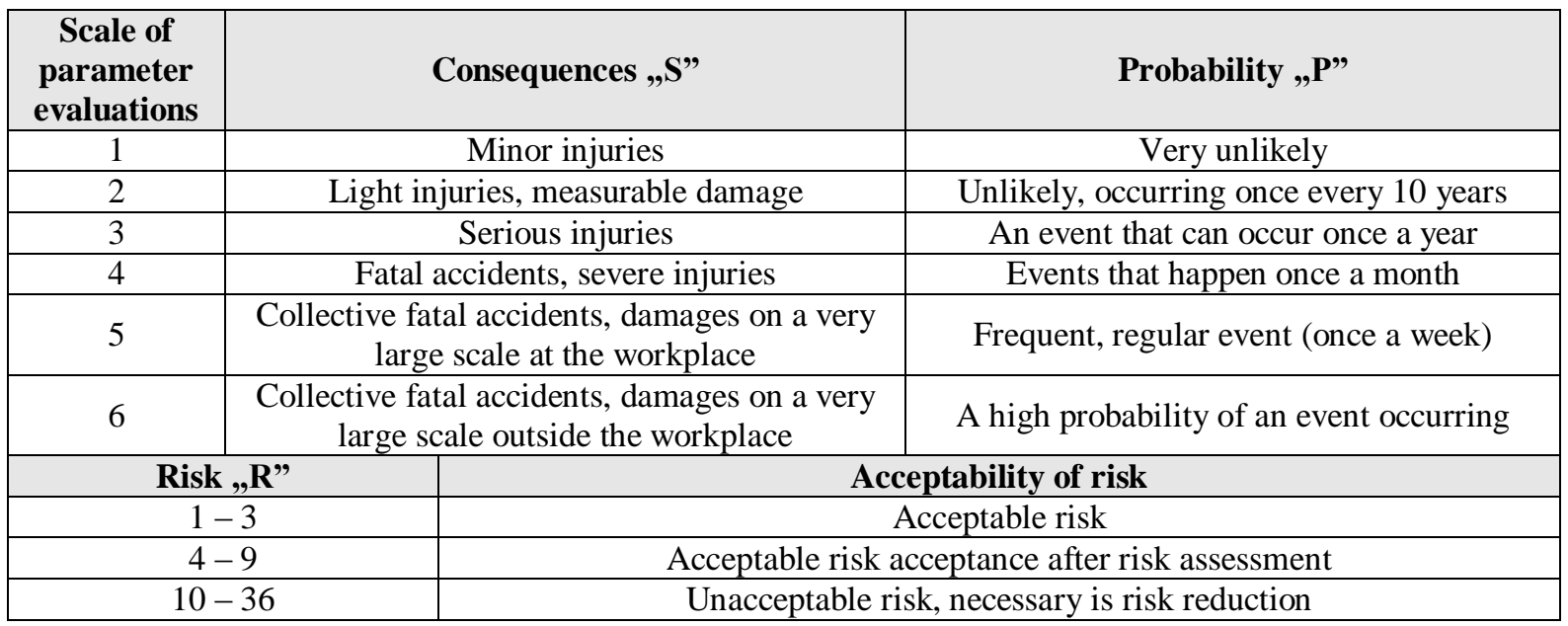

Source: own elaboration based on Lis, Nowacki, 2005.

Hazards related to the use of the rubber and plastic rolling machine (Table 2) were defined by indicators $(\mathrm{P}, \mathrm{S})$ and the risk was estimated. For hazards: physical load - static, perceptual load, emotional load, risk at the acceptable level was estimated $(\mathrm{R}=6)$. In case of hazards related to the moving parts of the machine, ejected material, lack of stability, the estimated risk level requires the employer to take immediate actions to reduce its occurrence. The risk for these hazards is unacceptable ( $\mathrm{R}=18, \mathrm{R}=18$ and $\mathrm{R}=24$, respectively). According to the adopted method of risk analysis and assessment, the proper measures should be applied to reduce the risk and ensure that the legal requirements are met.

The occurrence of hazards in the use of machinery requires employers to put in place preventive solutions to reduce the risk. In connection with the assessment of areas related to the safety and risk analysis, discrepancies in legal requirements have been uncovered. Table 2 identifies the area related to the safety and non-conformities (deficiencies in meeting the requirements) which have been referred to in the harmonized standards. The use of standards allows for the implementation of solutions limiting the risks associated with the use of a machine for rolling rubber and plastics.

The study analyzed the selected areas related to ensuring the safety of the machine (Table 2). For these areas, the actions that allow for the elimination or reduction of existing threats have been identified - a proposal for risk limitation measures.

One of the analyzed areas were control elements for which the same colour of the buttons was originally used, their function (purpose) was not described. Moreover, they were placed so that their use required the operator to take a forced position (physical, static, perceptual and emotional load). In order to eliminate the nuisance related to the performed work, harmonized standards were used. 
Table 2

The adaptation of the methodology of the approach to the assessment of compliance with legal requirements for an analyzed machine

\begin{tabular}{|c|c|c|c|c|c|}
\hline \multicolumn{6}{|c|}{ Identification of facilities, determining the date of their production } \\
\hline \multicolumn{2}{|c|}{ Machine: } & \multicolumn{4}{|c|}{ Rolling-mill for rubber and plastics } \\
\hline \multicolumn{2}{|c|}{ Production year: } & \multicolumn{4}{|l|}{1970} \\
\hline \multicolumn{2}{|c|}{ Type of legal requirements } & \multicolumn{4}{|l|}{ Minimum requirements } \\
\hline \multicolumn{6}{|c|}{$\begin{array}{l}\text { Legal requirements: } \\
\text { 1. Directive 2009/104/WE of the European Parliament and of the Council of } 16 \text { September } 2009 \text { concerning } \\
\text { the minimum safety and health requirements for the use of work equipment by workers at work (DN). } \\
\text { 2. Regulation of the Minister of Economy of } 30 \text { October } 2002 \text { on minimum safety and hygiene requirements } \\
\text { for the use of machines by workers at work (RMG). } \\
\text { 3. Regulation of the Minister of Labor and Social Policy of } 26 \text { September } 1997 \text { on general health and safety at } \\
\text { work regulations (RMPiPS). }\end{array}$} \\
\hline \multicolumn{6}{|c|}{ A list of security-related areas } \\
\hline \multicolumn{6}{|c|}{$\begin{array}{l}\text { - equipment control devices } \\
\text { - completely and safely stopping } \\
\text { - emergency stop } \\
\text { - falling and thrown objects } \\
\text { - guards and protection devices } \\
\text { - stability of the machinery (work equipment) } \\
\text { - warnings and markings necessary to ensure the safety of employees }\end{array}$} \\
\hline \multicolumn{6}{|c|}{ Assessment of compliance with legal requirements (for juxtaposed areas) } \\
\hline \multirow{2}{*}{ No. } & \multirow{2}{*}{\multicolumn{2}{|c|}{ Legal requirements }} & \multirow[t]{2}{*}{ Legal basis } & \multicolumn{2}{|c|}{$\begin{array}{l}\text { The fulfilment of } \\
\text { legal requirements }\end{array}$} \\
\hline & & & & Yes & No \\
\hline \multicolumn{6}{|c|}{ Area: Equipment control devices } \\
\hline 1 & $\begin{array}{l}\text { Work equipment con } \\
\text { clearly visible and } \\
\text { where necessary. }\end{array}$ & $\begin{array}{l}\text { l devices which affect safety must be } \\
\text { ntifiable and appropriately marked }\end{array}$ & $\begin{array}{c}\S 9.1(\mathrm{RMG}) \\
\S 52.3(\mathrm{RMPiPS}) \\
\text { p. } 2.1 .(\mathrm{DN})\end{array}$ & & $\mathrm{x}$ \\
\hline 2 & $\begin{array}{l}\text { Except where necess } \\
\text { devices must be loca } \\
\text { way that their operat } \\
\text { They must not give } \\
\text { unintentional operati }\end{array}$ & $\begin{array}{l}\text { for certain control devices, control } \\
\text { outside danger zones and in such a } \\
\text { cannot pose any additional hazard. } \\
\text { se to any hazard as a result of any }\end{array}$ & $\begin{array}{c}\S 9.2(\mathrm{RMG}) \\
\S 52.4(\mathrm{RMPiPS}) \\
\text { p. } 2.1(\mathrm{DN})\end{array}$ & & $\mathrm{x}$ \\
\hline \multicolumn{6}{|c|}{ Area: Completely and safely stopping } \\
\hline 3 & $\begin{array}{l}\text { All work equipment } \\
\text { completely and safel }\end{array}$ & ust be fitted with a control to stop it & $\begin{array}{c}\S 13.1(\mathrm{RMG}) \\
\S 52.1(\mathrm{RMPiPS}) \\
\text { p. } 2.3 .(\mathrm{DN})\end{array}$ & & $\mathrm{x}$ \\
\hline \multicolumn{6}{|c|}{ Area: Emergency stop } \\
\hline 4 & $\begin{array}{l}\text { Where appropriate, } \\
\text { equipment presents } \\
\text { equipment must be fi }\end{array}$ & $\begin{array}{l}\text { depending on the hazards the } \\
\text { d its normal stopping time, work } \\
\text { d with an emergency stop device. }\end{array}$ & $\begin{array}{c}\S 14.1(\mathrm{RMG}) \\
\S 52.2(\mathrm{RMPiPS}) \\
\text { p. } 2.4(\mathrm{DN})\end{array}$ & & $\mathrm{x}$ \\
\hline \multicolumn{6}{|c|}{ Area: Thrown objects, falling objects } \\
\hline 5 & $\begin{array}{l}\text { Work equipment pre } \\
\text { projections must be } \\
\text { corresponding to the }\end{array}$ & $\begin{array}{l}\text { nting risk due to falling objects or } \\
\text { ted with appropriate safety devices } \\
\text { k. }\end{array}$ & $\begin{array}{l}\S 14.2(\mathrm{RMG}) \\
\text { p. } 2.5(\mathrm{DN})\end{array}$ & & $\mathrm{x}$ \\
\hline \multicolumn{6}{|c|}{ Area: Guards and protection devices } \\
\hline 6 & $\begin{array}{l}\text { Where there is a ris } \\
\text { parts of work equipm } \\
\text { parts must be provid } \\
\text { access to danger zon } \\
\text { parts before the dang }\end{array}$ & $\begin{array}{l}\text { of mechanical contact with moving } \\
\text { it that could lead to accidents, those } \\
\text { with guards or devices to prevent } \\
\text { or to halt movements of dangerous } \\
\text { zones are reached. }\end{array}$ & $\begin{array}{c}\S 15.3(\mathrm{RMG}) \\
\text { p. } 2.8(\mathrm{DN}) \\
\S 55.1(\mathrm{RMPiPS})\end{array}$ & & $\mathrm{x}$ \\
\hline \multicolumn{6}{|c|}{ Area: Stability of the machinery } \\
\hline 7 & $\begin{array}{l}\text { Work equipment and } \\
\text { necessary for the safe } \\
\text { by clamping or some }\end{array}$ & $\begin{array}{l}\text { arts of such equipment must, where } \\
\text { and health of workers, be stabilised } \\
\text { her means. }\end{array}$ & $\begin{array}{l}\S 15.1(\mathrm{RMG}) \\
\text { p. } 2.6(\mathrm{DN})\end{array}$ & & $\mathrm{x}$ \\
\hline
\end{tabular}


Cont. table 2.

\begin{tabular}{|c|c|c|c|c|c|c|c|c|}
\hline \multicolumn{9}{|c|}{ Area: Warnings and markings necessary to ensure the safety of employees } \\
\hline 8 & \multicolumn{4}{|c|}{$\begin{array}{l}\text { Work equipment must bear the warnings and markings } \\
\text { essential to ensure the safety of workers. }\end{array}$} & $\begin{array}{l}\S 18.1 .2(\mathrm{RMG}) \\
\text { p. } 2.15(\mathrm{DN})\end{array}$ & & \multicolumn{2}{|c|}{$\mathrm{x}$} \\
\hline \multicolumn{9}{|c|}{ Identification of hazards and risk assessment } \\
\hline No. & \multicolumn{2}{|c|}{ Hazard } & Source of risk & & $\begin{array}{l}\text { Arising from potential } \\
\text { risk }\end{array}$ & $\mathbf{P}$ & $\mathbf{S}$ & $\mathbf{R}$ \\
\hline 1 & \multicolumn{2}{|c|}{ physical load - static } & location of the control panel & & tiredness, back pain & 6 & 1 & 6 \\
\hline 2 & \multicolumn{2}{|c|}{ perceptual load } & $\begin{array}{l}\text { marking of control elements, } \\
\text { markings on the machine }\end{array}$ & & tiredness & 6 & 1 & 6 \\
\hline 3 & \multicolumn{2}{|c|}{ emotional load (stress) } & $\begin{array}{l}\text { marking of control elements, } \\
\text { markings on the machine }\end{array}$ & & overstrung & 6 & 1 & 6 \\
\hline 4 & \multicolumn{2}{|c|}{$\begin{array}{l}\text { moving parts of the } \\
\text { machine }\end{array}$} & movable rollers & & crushing upper limbs & 6 & 3 & 18 \\
\hline 5 & \multicolumn{2}{|c|}{ ejected material } & material & & loss of vision & 6 & 3 & 18 \\
\hline 6 & \multicolumn{2}{|c|}{ lack of stability } & $\begin{array}{l}\text { lack of fixing the machine to } \\
\text { the ground }\end{array}$ & & $\begin{array}{l}\text { crushing of lower limbs, } \\
\text { death }\end{array}$ & 6 & 4 & 24 \\
\hline \multicolumn{9}{|c|}{ Determination of existing discrepancies. Elimination, reduction of occurring discrepancies } \\
\hline \multicolumn{2}{|c|}{ Analysed area } & & Inconsistencies & \multicolumn{5}{|c|}{$\begin{array}{c}\text { Reference to non-compliance to } \\
\text { harmonized standards }\end{array}$} \\
\hline \multicolumn{2}{|c|}{$\begin{array}{l}\text { equipment control } \\
\text { devices }\end{array}$} & \multicolumn{2}{|c|}{$\begin{array}{l}\text { unmarked control elements, uniform } \\
\text { colour of control elements, no } \\
\text { ergonomic arrangement of control } \\
\text { elements }\end{array}$} & \multicolumn{5}{|c|}{$\begin{array}{l}\text { PN-EN 61310-1:2009-p. } 4.1 . \\
\text { PN-EN 61310-2:2010-p. } 5.1 \text { and p. } 7 . \\
\text { PN-EN 61310-3:2010-p. } 4 . \\
\text { PN-EN 13850:2012-p. } 4.4 .5 \\
\text { PN-EN ISO 12100:2012-p. } 6.2 .8\end{array}$} \\
\hline \multicolumn{3}{|c|}{$\begin{array}{c}\text { Proposal of measures to limit } \\
\text { the risk }\end{array}$} & \multicolumn{6}{|c|}{$\begin{array}{l}\text { - mark the control elements legibly (Start, Stop) } \\
\text { - use the correct colours of the controls (green - start, red - stop, red button } \\
\text { on a yellow background - emergency stop switch) } \\
\text { - position the controls in the normal range and operator's field of vision }\end{array}$} \\
\hline \multicolumn{2}{|c|}{$\begin{array}{c}\text { ejected material, } \\
\text { substances, objects/ } \\
\text { guards or protective } \\
\text { devices }\end{array}$} & \multicolumn{2}{|c|}{$\begin{array}{l}\text { no guard protecting the employee from } \\
\text { the material being thrown away }\end{array}$} & \multicolumn{5}{|c|}{$\begin{array}{l}\text { PN-EN 1417:2015:04 - p. } 5.2 . \\
\text { PN-EN ISO 12100:2012-p. } 6.3 .2 \\
\text { PN-EN ISO 14120:2016 - p. } 5\end{array}$} \\
\hline \multicolumn{3}{|c|}{$\begin{array}{c}\text { Proposal of measures to limit } \\
\text { the risk }\end{array}$} & \multicolumn{6}{|c|}{$\begin{array}{l}\text { - install guard to limit access to the danger zone, so that the operator cannot } \\
\text { touch the moving rollers }\end{array}$} \\
\hline \multicolumn{2}{|c|}{ machine stability } & \multicolumn{2}{|c|}{$\begin{array}{l}\text { no attachment of the machine to the } \\
\text { ground to ensure its stability }\end{array}$} & \multicolumn{5}{|c|}{ PN-EN ISO 12100:2012 - p. 6.3.2.6. } \\
\hline \multicolumn{3}{|c|}{$\begin{array}{l}\text { Proposal of measures to limit } \\
\text { the risk }\end{array}$} & \multicolumn{6}{|c|}{ - fix the machine to the ground with anchor bolts } \\
\hline \multicolumn{2}{|c|}{$\begin{array}{l}\text { signs and marking } \\
\text { used to improve } \\
\text { safety }\end{array}$} & \multicolumn{2}{|c|}{$\begin{array}{c}\text { no marking informing about residual } \\
\text { risk }\end{array}$} & \multicolumn{5}{|c|}{$\begin{array}{l}\text { PN-EN ISO 12100:2012 - p. 6.4.4. } \\
\text { PN-EN 61310-1-2009- p. } 4.2 . \\
\text { PN-EN 60204-1:2010 - p. } 16.2 .\end{array}$} \\
\hline & me Hsk & to limit & $\begin{array}{l}\text { - on the machine, apply pict } \\
\text { personal protective equipmes } \\
\text { hazards) }\end{array}$ & & $\begin{array}{l}\text { ns informing about resid } \\
\text { formation about hot sur }\end{array}$ & & & \\
\hline & Di: & ( & ment of the effectiveness of $i$ & & enting risk mitigatio & & & \\
\hline No. & Hazard & & Implemented solutions & & uce the risk & $\mathbf{P}$ & $\mathbf{S}$ & $\mathbf{R}$ \\
\hline 1 & $\begin{array}{l}\text { physical load } \\
\text { static }\end{array}$ & posi & oning of control elements in no & hal & ergonometric range & 1 & 1 & 1 \\
\hline 2 & perceptual loa & $\begin{array}{l}\text { - leg } \\
\text { - use } \\
\text { the r } \\
\text { on a } \\
\text { - cor }\end{array}$ & $\begin{array}{l}\text { y labelling of control elements } \\
\text { lours to identify control eleme } \\
\text { uirements of the standards (gre } \\
\text { llow background - emergency } \\
\text { ol elements to be relocated int }\end{array}$ & & $\begin{array}{l}\text { Stop, Emergency Stop) } \\
\text { at are in accordance with } \\
\text { art, red - stop, red button } \\
\text { witch) } \\
\text { perator's field of vision }\end{array}$ & 1 & 1 & 1 \\
\hline 3 & $\begin{array}{l}\text { emotional loa } \\
\quad \text { (stress) }\end{array}$ & $\begin{array}{l}- \text { ma } \\
\text { - inf } \\
\text { - equ }\end{array}$ & $\begin{array}{l}\text { ing of control elements } \\
\text { mation on residual risk in the } \mathrm{f} \\
\text { oment controls to be relocated } \mathrm{i}\end{array}$ & & $\begin{array}{l}\text { f pictograms } \\
\text { lace that allows easy use }\end{array}$ & 1 & 1 & 1 \\
\hline
\end{tabular}


The limitation of the threat related risk - the lack of machine stability $(R=24$ to $R=4)$ was obtained thanks to ensuring the permanent connection of the machine to the ground by means of anchoring bolts. The usage of one of the solutions provided in the PN-EN ISO 12100:2012 standard allowed for meeting the requirements of the legislator set out in $\S 15.1$. (RMG), thereby reducing the risk of the machine overturning.

\section{Summary}

The subject of the evaluation was a machine for rolling rubber and plastics for which the process of implementing the methodology in the area of reducing inconsistencies and improving work safety was presented. The process of assessing the compliance with legal requirements and risk assessment was carried out for selected areas. The hazards related to the lack of machine stability $(\mathrm{R}=24)$, ejected material $(\mathrm{R}=18)$, moving parts of the machine $(\mathrm{R}=18)$ were estimated as unacceptable. However, for the psychophysical risks, the acceptability of risk was registered, with the probability value $\mathrm{P}=6-$ in accordance with the adopted risk analysis and assessment method (the occurrence of acceptable risk requires the employer to maintain it at such a level).

Determining the existing discrepancies in the scope of legal requirements, the unacceptable risk required taking actions aimed at improving work safety. The solution to this problem was possible thanks to the provisions described in the harmonized standards. The application of the solutions provided in the standards allowed for meeting the requirements of the legislator and limiting the risks associated with the use of the machine.

The methodical approach to the process of limiting and managing risk plays an important role in shaping health and safety standards at work in companies. The development of a methodical behaviour in the field of assessing legal requirements (minimum, essential) may be a useful tool for people who evaluate work safety levels for operating machines or the for the safety of machines put on the EU market. 


\section{References}

1. Dokumentacja techniczno-ruchowa walcarki do gumy i tworzyw sztucznych.

2. Dyrektywa 2006/42/WE Parlamentu Europejskiego i Rady z dnia 17 maja 2006 r. w sprawie maszyn.

3. Dyrektywa Parlamentu Europejskiego i Rady 2009/104/WE z dnia 16 września 2009 r. dotycząca minimalnych wymagań w dziedzinie bezpieczeństwa i higieny użytkowania sprzętu roboczego przez pracowników podczas pracy.

4. Lis, T., Nowacki, K. (2005). Zarządzanie bezpieczeństwem i higieną pracy w zakładzie przemysłowym. Wydawnictwo Politechniki Ślaskiej, 80-81.

5. Łabanowski, W. (2012). Bezpieczeństwo użytkowania maszyn. Poradnik dla pracodawców. Warszawa: Państwowa Inspekcja Pracy - Główny Inspektorat Pracy, 11-16.

6. Małysa, T., Lis, T., Nowacki, K. (2013). Wymagania prawne w zarządzaniu bezpieczeństwem użytkowania maszyn. In: R. Knosala (ed.), Innowacje w zarzadzaniu i inżynierii produkcji. Opole: Byblos, 1097-1107.

7. Małysa, T., Nowacki, K., Furman, J. (2016). The risk management methodology in the metallurgical enterprise. METAL 2016. 25th Anniversary International Conference on Metallurgy and Materials. Conference proceedings. Brno, Czech Republic, 25-27.05.2016, 1925-1930.

8. Małysa, T., Nowacki, K., Lis, T. (2015). Przegląd bezpieczeństwa użytkowania maszyn w przedsiębiorstwach przemysłowych. Hutnik - Wiadomości Hutnicze, 82(6), 409-415. DOI:10.15199/24.2015.6.5.

9. Małysa, T., Pawlak, S. (2017). Dobór rozwiązań profilaktycznych jako element poprawy bezpieczeństwa pracy przy użytkowaniu maszyn. Zeszyty Naukowe Politechniki Ślaskiej Seria: Organizacja $i$ Zarządzanie, 105, 267-270, http://dx.doi.org/10.29119/16413466.2017.105.20.

10. PN-EN 1417:2015-04 Maszyny do przetwórstwa tworzyw sztucznych i mieszanek gumowych - Walcarki dwuwalcowe - Wymagania bezpieczeństwa.

11. PN-EN 349+A1:2010 Bezpieczeństwo maszyn. Minimalne odstępy zapobiegające zgnieceniu części ciała człowieka.

12. PN-EN 60204-1 Bezpieczeństwo maszyn. Wyposażenie elektryczne maszyn - Część 1: Wymagania ogólne.

13. PN-EN 61310-1:2009 Bezpieczeństwo maszyn. Wskazywanie, oznaczanie i sterowanie. Część 1: Wymagania dotyczące sygnałów wizualnych, akustycznych i dotykowych.

14. PN-EN 61310-2:2010 Bezpieczeństwo maszyn. Wskazywanie, oznaczanie i sterowanie. Część 2: Wymagania dotyczące oznaczania.

15. PN-EN 61310-3:2010 Bezpieczeństwo maszyn. Wskazywanie, oznaczanie i sterowanie. Część 3: Wymagania dotyczące umiejscowienia i działania elementów sterowniczych. 
16. PN-EN ISO 12100:2012 Bezpieczeństwo maszyn - Ogólne zasady projektowania - Ocena ryzyka i zmniejszanie ryzyka.

17. PN-EN ISO 13850:2012 Bezpieczeństwo maszyn. Zatrzymanie awaryjne zasady projektowania.

18. PN-EN ISO 13857:2010 Bezpieczeństwo maszyn. Odległości bezpieczeństwa uniemożliwiające sięganie kończynami górnymi i dolnymi do stref niebezpiecznych.

19. PN-EN ISO 14120:2016 Bezpieczeństwo maszyn - Osłony - Ogólne wymagania dotyczące projektowania i budowy osłon stałych i ruchomych.

20. Rozporządzenie Ministra Gospodarki z dnia 21 października 2008 r. w sprawie wymagań zasadniczych dla maszyn (Dz.U. 2011.124.701).

21. Rozporządzenie Ministra Gospodarki z dnia 30 października 2002 r. w sprawie minimalnych wymagań bezpieczeństwa i higieny użytkowania maszyn przez pracowników podczas pracy (Dz.U. 2003.178.1745).

22. Rozporządzenie Ministra Pracy i Polityki Socjalnej z dnia 26 września 1997 r. w sprawie ogólnych przepisów bezpieczeństwa i higieny pracy (Dz.U. 2011.173.1034).

23. Szlęzak, J., Szlęzak, N. (2012). Bezpieczeństwo i higiena pracy. Wydawnictwo AGH, 54-55.

24. Ustawa z dania 13 kwietnia 2016 r. o systemach oceny zgodności i nadzoru rynku (Dz.U. 2016.542).

25. Ustawa z dnia 26 czerwca 1974 r. Kodeks pracy (Dz.U. 2018.1629). 